Table 1. Comparison of data derived from determinations of the ionic conductivity, rotational (Grotthuss Mechanism) and translational (Vehicle Mechanism) modes for two proton conductors.

\begin{tabular}{|c|c|c|c|c|}
\hline Compound & Process & $\begin{array}{l}\text { Activation } \\
\text { Enthalpy }[\mathrm{eV}]\end{array}$ & $\begin{array}{l}\text { Jump Frequency } \\
\text { at Room Temperature } \\
{\left[\mathrm{s}^{-1}\right]}\end{array}$ & Measurement \\
\hline \multirow[t]{3}{*}{$\mathrm{HUO}_{2} \mathrm{AsO}_{4} \cdot 4 \mathrm{H}_{2} \mathrm{O}$} & conductivity & $0.64 \pm 0.03$ & $10^{9}$ & complex impedance \\
\hline & $\mathrm{H}_{2} \mathrm{O}$ rotation & $0.27 \pm 0.02$ & $10^{n}$ & ${ }^{t} \mathbf{H}-\mathrm{NMR}[\mathrm{a}]$ \\
\hline & $\mathrm{H}_{2} \mathrm{O}$ translation & $0.8 \pm 0.2$ & $3 \times 10^{4}$ & ${ }^{1 \times} \mathrm{O}$ self-diffusion, $\mathrm{H}_{2} \mathrm{O}$ desorption \\
\hline \multirow[t]{3}{*}{$\mathrm{LiN}_{2} \mathrm{H}_{5} \mathrm{SO}_{4}$} & conductivity & $0.75 \pm 0.07$ & - & complex impedance $[4]$ \\
\hline & $-\mathrm{NH}_{3}^{+}$rotation & $0.19 \pm 0.01$ & - & 'H-NMR [5] \\
\hline & $\mathrm{N}_{2} \mathbf{H}_{5}^{+}$translation & $0.7 \pm 0.04$ & - & 'H-NMR [5] \\
\hline
\end{tabular}

[a] In collaboration with $R$. Messer, Max-Planck-Institut für Metallforschung, Stuttgart.

conductors are good ion-exchangers, in which oxonium ions are always exchanged, but individual protons never, e.g.,

$\mathrm{HUO}_{2} \mathrm{AsO}_{4} \cdot 4 \mathrm{H}_{2} \mathrm{O}+\mathrm{Na}^{+} \rightleftharpoons \mathrm{NaUO}_{2} \mathrm{AsO}_{4} \cdot 3 \mathrm{H}_{2} \mathrm{O}+\mathrm{H}_{3} \mathrm{O}^{+}$

Using the Vehicle Mechanism as a working principle a series of new proton conductors have been found ${ }^{[3 a \mid}$. In particular proton conduction in zeolites has been optimized. Since the Vehicle Mechanism no longer requires an infinite hydrogen bond network, much stronger basic species, e.g. $\mathrm{NH}_{3}$, which have a high self-diffusion coefficient, can be used. In the case of zeolites this is particularly important, since $\mathrm{NH}_{3}$, in contrast to $\mathrm{H}_{2} \mathrm{O}$, is capable of binding a proton from the amphoteric host lattice with formation of $\mathrm{NH}_{4}^{+}$.

The concept of the Vehicle Mechanism leads to new applications of solid proton conductors in electrochemical cells ${ }^{[3 b]}$. Whereas the previously discussed mechanisms are based on pure proton transport between electrodes of different $\mathrm{H}$-activity-as, e.g., mixed conducting hydrideselectrodes of different oxygen activity can now also be taken into consideration. The transport of protons and water molecules in opposite direction give together an overall transport of $\mathrm{O}^{2-}$. For example, proton conductors have already been used as electrolytes in metal-air and metal $/ \mathrm{me}$ tal oxide cells (Table 2).

Table 2. Properties of some galvanic elements with hydrated $\mathrm{NH}_{4}$-zeolite $\mathrm{A}$ as separator material.

\begin{tabular}{lllc}
\hline Anode & Cathode & $\begin{array}{l}\text { Observed Open Cell } \\
\text { Potential [V] }\end{array}$ & $\begin{array}{l}\text { Observed Short Circuit } \\
\text { Current Density }\left[\mu \mathrm{A} \mathrm{cm}^{-2}\right]\end{array}$ \\
\hline $\mathrm{Fe}$ & $\mathrm{MnO}_{2}$ & $0.7-1.2$ & 120 \\
$\mathrm{Sn}$ & $\mathrm{MnO}_{2}$ & 0.85 & 80 \\
$\mathrm{Zn}$ & $\mathrm{MnO}_{2}$ & 1.3 & 800 \\
$\mathrm{Zn}$ & $\mathrm{PbO}_{2}$ & 1.7 & 5000 \\
\hline
\end{tabular}

Received: November 25, 198$]$ [Z 32 IE] German version: Angew. Chem. 94 (1982) 224

[1] a) A. T. Howe, M. G. Shilton, J. Solid State Chem. 23 (1979) 345; 34 (1980) 149 ; b) L. Bernard, A. Fitch, A. F. Wright, B. E. F. Fender, A. T. Howe, Solid State Ionics 5 (1981) 459.

[2] Groups such as $\mathrm{OH}_{3}^{+}$or even $\mathrm{NH}_{4}^{+}$have been detected IR spectroscopically in solid proton conductors.

[3] a) M. Bell et al., DBP application, Az P 3127821.3 (1981); K. D. Kreuer, A. Rabenau, T. W. Weppner, Mat. Res. Bull. 17 (1982), in press; b) K. D. Krever et al., DBP application, Az P 3127820.5 (1981).

[4] K. D. Kreuer, W. Weppner, A. Rabenau, Solid State Ionics 3/4 (1981) 353.

[5] R. R. Knispel, H. E. Petch, Can. J. Phys. 49 (1971) 870.

\section{Photochemical Oxidative Addition of Chlorine from Chloroform to 2,2'-Bipyridyldichloroplatinum(II) **}

By Arnd Vogler* and Horst Kunkely

The mechanism of light-induced multielectron transfer has been little studied. Increasing interest is being shown in reactions of this type in relation to photosynthesis, or to the photochemical splitting of water. Particularly important two-electron redox reactions of complexes are reductive elimination and oxidative addition. Some light-induced reductive eliminations have been studied in depth $^{[1]}$. In addition, a series of photolytic oxidative additions is known ${ }^{[1 b]}$. However, in all cases the primary photochemical step consists of the release of a ligand. Consequently, oxidative addition is not strictly a photochemical reaction, but occurs more frequently as a thermal reaction at coordinatively unsaturated, reactive metal complexes. We report the first oxidative addition as the primary step in a photochemical reaction.

Irradiation of $\left[\mathrm{Pt}^{1 \mathrm{I}}(\mathrm{bpy}) \mathrm{Cl}_{2}\right]^{[2]}$ in acetonitrile led, in the absence of side-reactions, to substitution of chloride with formation of [Pt(bpy) $\left.\left(\mathrm{CH}_{3} \mathrm{CN}\right) \mathrm{Cl}\right]^{\oplus}$; irradiation at the long wavelength band of the complex $(\lambda \geq 320 \mathrm{~nm})$ was sufficient. The reaction did not proceed in $\mathrm{CHCl}_{3}$ solutions. In contrast $\left[\mathrm{Pt}^{\prime \prime}(\mathrm{bpy}) \mathrm{Cl}_{2}\right]$ is smoothly oxidized to

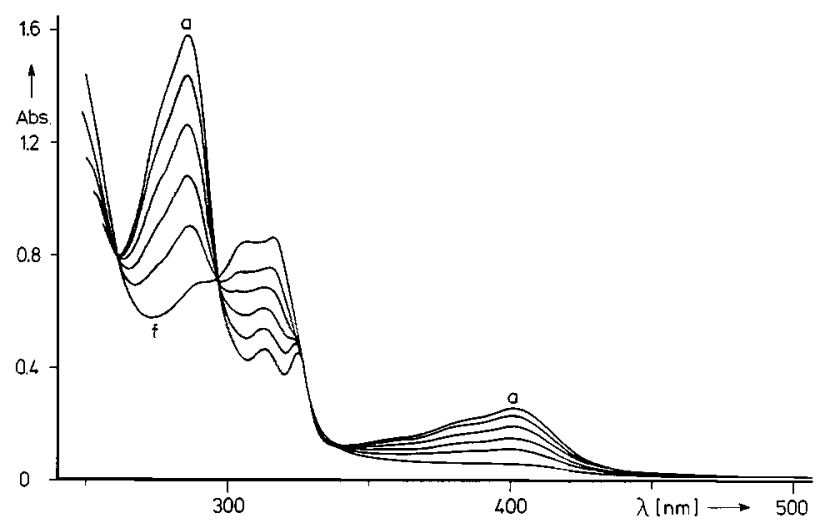

Fig. 1. Changes in the absorption spectrum during photolysis of $\left[\mathrm{Pt}(\mathrm{bpy}) \mathrm{Cl}_{2}\right]$ $\left(8.78 \times 10^{-5} \mathrm{~mol} / \mathrm{L}\right)$ in $\mathrm{CHCl}_{3}$ in a $1 \mathrm{~cm}$ cuvette, excitation light: $\lambda>280 \mathrm{~nm}$, irradiation time: $a=0, f=10 \mathrm{~min}$.

[*] Prof. Dr. A. Vogler, Dr. H. Kunkely Institut für Anorganische Chemie der Universität Universitätsstr. 31 , D-8400 Regensburg 2 (Germany)

$\left[{ }^{* *}\right]$ This work was supported by the Deutsche Forschungsgemeinschaft and the Fonds der Chemischen Industrie. 
$\left[\mathrm{Pt}^{\mathrm{IV}}(\mathrm{bpy}) \mathrm{Cl}_{4}\right]^{[2]}$ when shorter wavelength light $(280<\lambda<300 \mathrm{~nm})$ is used for the irradiation. The spectral changes during photolysis (Fig. 1) can be simulated by oxidation of $\left[\mathrm{Pt}(\mathrm{bpy}) \mathrm{Cl}_{2}\right.$ ] with $\mathrm{Cl}_{2}$, or by reduction of [Pt(bpy)Cl ${ }_{4}$ ] with $\mathrm{NaBH}_{4}$. The quantum yield of the photooxidation was $\phi=0.06$ for irradiation with $\lambda=280 \mathrm{~nm}$.

From these results it is improbable that a coordinatively unsaturated complex is formed in the primary photochemical step by release of a ligand. Summarizing, the following mechanism is proposed:

$$
\begin{aligned}
& {\left[\mathrm{Pt}^{\prime \prime}(\text { bpy }) \mathrm{Cl}_{2}\right]+\mathrm{CHCl}_{3} \longrightarrow\left[\mathrm{Pt}^{\prime \prime \prime}(\text { bpy }) \mathrm{Cl}_{3}\right]+{ }^{\circ} \mathrm{CHCl}_{2}} \\
& {\left[\mathrm{Pt}^{\prime \prime \prime}(\text { bpy }) \mathrm{Cl}_{3}\right]+{ }^{\ominus} \mathrm{CHCl}_{2} \longrightarrow\left[\mathrm{Pt}^{\prime \mathrm{v}}(\mathrm{bpy}) \mathrm{Cl}_{3}\right]^{\oplus}+\mathrm{CHCl}_{2}^{\ominus}} \\
& {\left[\mathrm{Pt}^{\mathrm{IV}}(\mathrm{bpy}) \mathrm{Cl}_{3}\right]^{\oplus}+\mathrm{CHCl}_{2}^{\ominus} \longrightarrow\left[\mathrm{Pt}^{\prime \mathrm{V}}(\mathrm{bpy}) \mathrm{Cl}_{4}\right]+: \mathrm{CHCl}}
\end{aligned}
$$

Two-electron reductions are well known for geminal dichlorides $\mathrm{CR}_{2} \mathrm{Cl}_{2}{ }^{[3]}$. In the initial step an electron is taken up via formation of ${ }^{\odot} \mathrm{CR}_{2} \mathrm{Cl}$ and $\mathrm{Cl}^{\ominus}$. The radicals ${ }^{\circ} \mathrm{CR}{ }_{2} \mathrm{Cl}$ are powerful oxidizing agents, which are able to rapidly add a further electron to form the $\mathrm{CR}_{2} \mathrm{Cl}^{\ominus}$ anion. This reaction mechanism is thus to be expected in all cases involving the reaction of geminal dichlorides with a twoelectron reducing agent such as $\mathrm{Pt}^{\mathrm{II}}$. Presumably the intermediate products [ $\mathrm{Pt}$ "' (bpy) $\mathrm{Cl}_{3}$ ] and ${ }^{\circ} \mathrm{CHCl}_{2}$ have a very short lifetime and rapidly exchange a further electron to form $\mathrm{Pt}^{\mathrm{lV}}$. In accord with this assumption radicals could not be detected during the photolysis. ESR signals could neither be registered during low temperature photolysis at $77 \mathrm{~K}$ nor by irradiation at room temperature in the presence of $N$-benzylidene-tert-butylamine $N$-oxide ( $N$-tert-butylphenylnitron) as spin trap.

In the last step of the oxidative addition, the anion $\mathrm{CHCl}_{2}^{\ominus}$ could add directly as a sixth ligand to the coordinatively unsaturated complex $\left[\mathrm{Pt}^{\prime \prime}(\mathrm{bpy}) \mathrm{Cl}_{3}\right]^{\oplus}$ to form $\left[\mathrm{Pt}^{\mathrm{IV}}(\mathrm{bpy}) \mathrm{Cl}_{3}\left(\mathrm{CHCl}_{2}\right)\right]$. This type of oxidative addition of chlorinated alkanes such as dichloromethane to Pt" complexes is a well known thermal reaction ${ }^{[4]}$. In our example, however, the complex removes a chloride ion from the anion $\mathrm{CHCl}_{2}^{\ominus}$. Thereby $\left[\mathrm{Pt}^{\mathrm{IV}}\right.$ (bpy) $\left.\mathrm{Cl}_{4}\right]$ is formed as a stable end product together with monochlorocarbene. Apparently, this carbene reacts with a further chloroform molecule by insertion into its $\mathrm{C}-\mathrm{Cl}$ bond resulting in formation of 1,1,2,2-tetrachloroethane, which was detected by gas chromatography. This insertion reaction is a well known reaction type of carbenes ${ }^{[5]}$. Attempts to trap the monochlorocarbene with 2,3-dimethyl-2-butene did not lead to unambiguous results. At low concentrations of olefin $\left(\mathrm{ca} .10^{-3}\right.$ $\mathrm{mol} / \mathrm{L}$ ) the carbene reacts preferentially with solvent. With markedly higher concentrations of olefin the solubility of the complex is too low. In addition, complications from substitution reactions arise.

Received: July 7, 1981 [Z 29 IE] German version: Angew. Chem. 94 (1982) 217

[1] a) A. Vogler, R. E. Wright, H. Kunkely, Angew. Chem. 92 (1980) 745; Angew. Chem. Int. Ed. Engl. 19 (1980) 717, and references cited therein: b) G. L. Geoffroy, M. S. Wrighton: Organometallic Photochemistry, Academic Press, New York 1979.

[2] G. T. Morgan, F. H. Burstall, J. Chem. Soc. 1934, 965.

[3] a) A. J. Fry, R. G. Reed, J. Am. Chem. Soc. 94 (1972) 8475; b) H. P. Fritz, W. Kornrumpf, Justus Liebigs Ann. Chem. 1978, 1416, and references cited therein.

[4] G. B. Young, G. M. Whitesides, J. Am. Chem. Soc. 100 (1978) 5808.

[5] a) W. Kirmse: Carbene Chemistry, Academic Press, New York 1971; b) M. Jones, R. A. Moss: Carbenes, Vol. I and II, Wiley, New York 1973 and 1975 , respectively.

\section{Diastereoselective Synthesis of D,L-Sphingosine**}

\section{By Richard R. Schmidt* and Rudolf Kläger}

Sphingosine 1, an important membrane component, was previously accessible from achiral educts only via several steps involving formation of threo- and erythro-products $^{[1.2]}$. The natural product could be prepared-albeit in low yields-in more than ten steps from D-glucose $\mathrm{e}^{[3]}$. According to the progress made in the diastereoselective synthesis of acyclic systems ${ }^{[4]}$ it should be possible to prepare erythro-configurated $\mathrm{D}, \mathrm{L}-\mathrm{sphingosine.}$

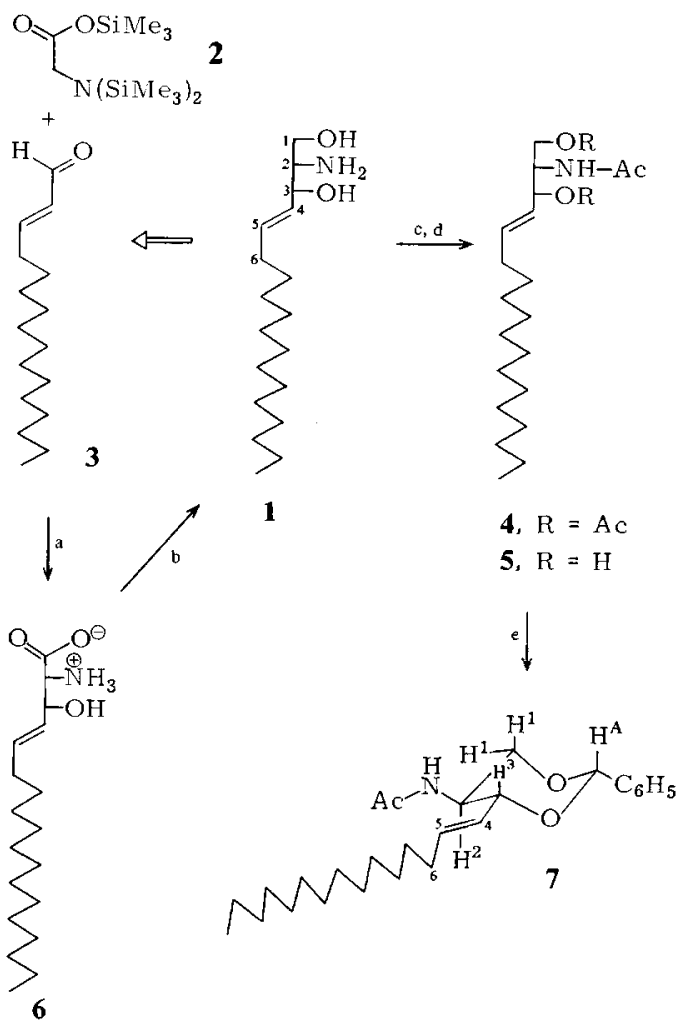

Scheme 1. a: LDA in THF, $-80^{\circ} \mathrm{C}, 1.5 \mathrm{~h}$; yield $59-75 \%$ 6, m.p. $=192$ $193^{\circ} \mathrm{C}$ (dec.) from DMF. - b: 7 equiv. $\mathrm{LiAlH}_{4}$ in THF, reflux, $36 \mathrm{~h}$; yield $90 \%$ $1 ; R_{\mathrm{F}}=0.2\left(\mathrm{DC}\right.$, silica gel, $\mathrm{CHCl}_{3}:$ methanol $\left.=1: 1\right) .-\mathrm{c}$ : pyridine $/ \mathrm{Ac}_{2} \mathrm{O}, \mathrm{RT}$, $15 \mathrm{~h}$; yield $50 \%$ 4; m.p. $=90-91^{\circ} \mathrm{C}$ (Lit. [1]: $91-92^{\circ} \mathrm{C}$ ) $-\mathrm{d}: \mathrm{NaOMe}$ in $\mathrm{MeOH}, \mathrm{RT}, \mathrm{I}$ h; yield $91 \% \mathrm{5} ; \mathrm{m} . \mathrm{p} .=85-87^{\circ} \mathrm{C}$. $-\mathrm{e}: 3$ equiv. $\mathrm{C}_{6} \mathrm{H}_{5}-\mathrm{CHO}$ and $\mathrm{I}$ equiv. $\mathrm{ZnCl}_{2}$ in toluene, RT, $16 \mathrm{~h}$; yield $89 \% 7, \mathrm{~m} . \mathrm{p} .=114-115^{\circ} \mathrm{C}$ from petroleum ether $\left(40-60^{\circ} \mathrm{C}\right) /$ ethyl acetate $=50: 1$.

We allowed the $\alpha, \beta$-unsaturated $C_{16}$-aldehyde 3 to react with the $\alpha$-carbanion of the protected glycine 2 (Scheme 1), since good results had already been achieved in this reaction with simple aldehydes ${ }^{\left[{ }^{\mid}\right]}$. The erythro-configurated, unsaturated $\beta$-hydroxy- $\alpha$-amino acid 6 was formed exclusively.

The structure of 6 was confirmed by reduction with $\mathrm{LiAlH}_{4}$ to the D, L-sphingosine $1(90 \%)$ and conversion of the latter into the triacetyl derivative $4^{[1]}$. Moreover, cleavage of the $O$-acetyl groups to give 5 and subsequent reaction with benzaldehyde afforded a 1,3-dioxane derivative 7; the trans arrangement of $\mathrm{H}^{2}$ and $\mathrm{H}^{3}$, as is expected for the erythro-configuration, is demonstrated in the ${ }^{1} \mathrm{H}-\mathrm{NMR}$ spectrum by the typical coupling constant of $8.9 \mathrm{~Hz}$ for

[*] Prof. Dr. R. R. Schmidt, R. Kläger Fakultăt für Chemie der Universităt Postfach 5560, D-7750 Konstanz (Germany)

$\left[{ }^{* *}\right]$ This work was supported by the Deutsche Forschungsgemeinschaft and the Fonds der Chemischen Industrie. 